\section{Kentucky Bluegrass Control with Postemergence Herbicides}

\author{
Patrick E. McCullough ${ }^{1}$ and Stephen E. Hart ${ }^{2}$ \\ Department of Plant Biology and Pathology, Rutgers, The State University of \\ New Jersey, New Brunswick, NJ 08901-8520
}

\author{
Shawn Askew ${ }^{3}$ \\ Department of Plant Pathology,Physiology, and Weed Science Virginia \\ Polytechnic Institute and State University, Blacksburg, VA 24061-0330
}

Peter H. Dernoeden ${ }^{4}$

Department of Natural Resource Sciences and Landscape Architecture, University of Maryland, College Park, MD 20742

\section{Zachary Reicher ${ }^{5}$ and Dan Weisenberger ${ }^{6}$ \\ Department of Agronomy, Purdue University, West Lafayette, IN 47907}

\begin{abstract}
With the potential introduction of glyphosate-resistant kentucky bluegrass (GRKB) (Poa pratensis L.), postemergence herbicides must be identified for renovation from glyphosate-resistant stands or control escaped GRKB. Field experiments were conducted in Indiana, Maryland, New Jersey, and Virginia from July to September 2004 to investigate efficacy of postemergence herbicides for kentucky bluegrass control. Herbicides tested included clethodim at $0.28 \mathrm{~kg} \cdot \mathrm{ha}^{-1}$ (a.i.), fluazifop-p at $0.43 \mathrm{~kg} \cdot \mathrm{ha}^{-1}$ (a.i.), formasulfuron at $0.03 \mathrm{~kg} \cdot \mathrm{ha}^{-1}$ (a.i.), glufosinate at $1.12 \mathrm{~kg} \cdot \mathrm{ha}^{-1}$ (a.i.), glyphosate at $1.68 \mathrm{~kg} \cdot \mathrm{ha}^{-1}$ (a.i.), rimsulfuron at $0.03 \mathrm{~kg} \cdot \mathrm{ha}^{-1}$ (a.i.), sethoxydim at $0.53 \mathrm{~kg} \cdot \mathrm{ha}^{-1}$ (a.i.), and trifloxysulfuron at 0.03 $\mathrm{kg} \cdot \mathrm{ha}^{-1}$ (a.i.). One and two applications of each herbicide were applied to separate plots with the sequential applied 4 weeks after initial treatments (WAIT). Single applications of glyphosate completely controlled kentucky bluegrass 4 WAIT in Maryland, New Jersey, and Virginia. Glufosinate completely controlled kentucky bluegrass with one application in Maryland and New Jersey but single and sequential applications provided only $80 \%$ to $88 \%$ control in Indiana and Virginia. Foramsulfuron and rimsulfuron required sequential applications for complete kentucky bluegrass control 8 WAIT in New Jersey and Maryland but $<\mathbf{8 2} \%$ control was obtained in Indiana and Virginia. Trifloxysulfuron controlled kentucky bluegrass $95 \%$ to $100 \%$ with single applications in Maryland, New Jersey, and Virginia. Single applications of clethodim, fluazifop, and sethoxydim provided minimal stand reductions but sequential applications controlled kentucky bluegrass $65 \%$ to $100 \%$. Results suggest glufosinate and trifloxysulfuron have the greatest potential for controlling GRKB while other herbicides provided erratic control and require sequential applications.
\end{abstract}

Glyphosate is a nonselective herbicide that controls a broad spectrum of annual and perennial grasses and broadleaf weeds (Syngenta, 2002c). On golf courses, lawns, landscapes, sod farms, and turfgrass seed production fields, glyphosate is commonly used for the control of turfgrass species in areas where they are undesirable. In addition, glyphosate is often used to desiccate existing turfgrass stands for renovations.

Glyphosate controls plants by inhibiting the enzyme 5-enolpyruvylshikimate-3-phosphate (EPSP) synthase, which is involved in the synthesis of aromatic amino acids (Amrhein, 1980). Advantages of using glyphosate include its relatively low-cost and favorable toxico-

\footnotetext{
Received for publication 30 Apr. 2005. Accepted for publication 18 June 2005.

${ }^{1}$ Progam associate. To whom reprint requests should be addressed; e-mail mccullough@aesop. rutgers.edu.

${ }^{2}$ Associate professor.

${ }^{3}$ Assistant professor.

${ }^{4}$ Professor.

${ }^{5}$ Associate professor

${ }^{6}$ Research agronomist.
}

fluazifop-P and clethodim effectively controlled creeping bentgrass and suggested the ACCase inhibiting herbicides may be utilized as alternative herbicides in the development of integrated management strategies for control of glyphosate-resistant bentgrass. Several of these herbicides such as clethodim, fluazifop-P, and sethoxydim are also labeled for broadcast or directed applications in landscape planting beds and some turfgrass species for control of unwanted annual and perennial grass species (BASF Corp. and MicroFlo Co., 2002e; Syngenta, 2002b; Valent Corp., 2002a). Researchers have also observed that fluazifop-P and sethoxydim were highly phytotoxic to 'Penncross' creeping bentgrass (Agrosits stolonifera Huds.) (Higgins et al., 1987).

Another potential alternative for controlling glyphosate-resistant turf species is glufosinate. Glufosinate is a nonselective herbicide which inhibits the enzyme glutamine synthase, resulting in a toxic accumulation of ammonia in plant cells and disruption of photosynthesis (Logusch etal., 1991; Wild et al., 1987; Wild and Wendler 1993). Askew et al. (2004) noted sequential applications of glufosinate controlled creeping bentgrass $96 \%$ to $100 \%$.

Herbicides in the sulfonylurea family such as rimsulfuron, trifloxysulfuron, and formasulfuron control many annual and perennial grass species and in some instances can be used in turf and noncrop sites (Bayer Environmental Sciences, 2003b; Griffin L.L.C., 2002d; Valent Corp., 2003a). These herbicides control plants by inhibiting acetolactate synthase, a key enzyme in the biosynthesis of the branchedchain amino acids isoleucine, leucine, and valine (Chaleff and Mauvais, 1984; Shaner et al., 1984; Stidham, 1991).

Currently, kentucky bluegrass cultivars are being developed with glyphosate resistance mechanisms (Riego, personal communication). Kentucky bluegrass is widely used throughout the northeastern U.S. for its desirable color, quality, and cold tolerance for lawns, sports fields, golf courses, and commercial turf sites (Beard, 1973). Kentucky bluegrass is generally not found as a weedy species, unlike creeping bentgrass, but control with postemergence herbicides may be needed for renovations.

The objective of this experiment was to investigate efficacy of postemergence herbicide alternatives to glyphosate for kentucky bluegrass control.

\section{Materials and Methods}

Field experiments were conducted in Adelphia, N.J., College Park, Md., West Lafayette, Ind., and Blacksburg, Va., from July to September 2004. The experimental design was a randomized complete block consisting of 17 treatments with four replications. Control plots were included per block. Trial information by location is presented in Table 1. Single versus two applications of clethodim, fluazifop-p, formasulfuron, glufosinate, glyphosate, rimsulfuron, sethoxydim, and trifloxysulfuron were evaluated on separate plots. Rates and formulations are presented in Table 2. Initial and sequential application dates were 8 July 
Table 1. Information from four locations for experiments conducted July to September 2004 investigating postemergence herbicides for kentucky bluegrass control.

\begin{tabular}{|c|c|c|c|c|c|c|c|c|}
\hline Location & Cultivar & $\begin{array}{l}\text { Stand } \\
\text { age } \\
\text { (years) }\end{array}$ & $\begin{array}{l}\text { Plot } \\
\text { size } \\
(\mathrm{m})\end{array}$ & $\begin{array}{l}\text { Soil } \\
\text { type }\end{array}$ & $\begin{array}{l}\text { Soil } \\
\mathrm{pH}\end{array}$ & $\begin{array}{c}\text { Application } \\
\text { vol }^{\mathrm{z}} \\
\left(\mathrm{L} \cdot \mathrm{ha}^{-1}\right)\end{array}$ & Nozzle $^{y}$ & $\begin{array}{c}\mathrm{CO}_{2} \\
\text { pressure } \\
(\mathrm{kPa})\end{array}$ \\
\hline Indiana & $\begin{array}{l}\text { Merit, Fairfax, } \\
\text { Freedom, SR2 } 100\end{array}$ & 6 & $1.5 \times 1.5$ & Starks-Fincastle Loam & 7.2 & 407 & $8001.5(3)$ & 240 \\
\hline Marlyand & Impact & 2 & $1.5 \times 1.5$ & Keyport Silt Loam & 5.9 & 460 & 8004E (1) & 240 \\
\hline New Jersey & Baron & 3 & $1 \times 3$ & Holmdel Sandy Loam & 6.5 & 370 & 9504E (1) & 220 \\
\hline Virginia & Kelly & 9 & $1.8 \times 1.8$ & Groseclose loam & 6.6 & 280 & VS11004 (4) & 275 \\
\hline
\end{tabular}

${ }^{\mathrm{z}}$ Initial and sequential application dates were 8 July and 6 Aug. 2004 in Indiana, 16 Aug. and 13 Sept. 2004 in Maryland, 13 July and 10 Aug. 2004 in Virginia, and 6 Aug. and 3 Sept. 2004 in New Jersey.

${ }^{y}$ Number in parenthesis indicates how many nozzles used per boom.

Table 2. Herbicide formulations and rates applied to kentucky bluegrass in Indiana, Maryland, New Jersey, and Virginia in Fall 2004.

\begin{tabular}{|c|c|c|}
\hline Herbicide $^{z}$ & Formulation & $\begin{array}{c}\text { Rate } \\
\left(\mathrm{kg} \cdot \mathrm{ha}^{-1} \text { a.i. }\right)\end{array}$ \\
\hline$\overline{\text { Clethodim }}^{\mathrm{y}}$ & $0.94 \mathrm{EC}$ & 0.28 \\
\hline Fluazifop-p ${ }^{y}$ & $2 \mathrm{EC}$ & 0.43 \\
\hline Foramsulfuron & $0.19 \mathrm{SC}$ & 0.03 \\
\hline Glufosinate & $1 \mathrm{SL}$ & 1.12 \\
\hline Glyphosate & $3 \mathrm{SL}$ & 1.68 \\
\hline Rimsulfuron $^{x}$ & $25 \mathrm{DF}$ & 0.03 \\
\hline Sethoxydim ${ }^{y}$ & $1 \mathrm{EC}$ & 0.53 \\
\hline Trifloxysulfuron $^{\mathrm{x}}$ & $75 \mathrm{WG}$ & 0.03 \\
\hline
\end{tabular}

${ }^{\mathrm{z}}$ Herbicide products applied were as follows. Envoy (clethodim 0.94EC), Valent U.S.A. Corp., Walnut Creek, Calif.; Finale (glufosinate 1SL), Aventis Environmental Science USA LP, Montvale, N.J.; Fusilade II (fluazifop-P 2EC) Turf and Ornamental, Syngenta Professional Products Division, Greensboro, N.C.; RoundupPro (glyphosate 3SL), Monsanto Co. St. Louis, Mo.; TranXit (rimsulfuron 25DF), Griffin L.L.C., Valdosta, Ga.; Vantage (sethoxydim 1EC), BASF Corp. and MicroFlo Co., Memphis, Tenn.; Monument (trifloxysulfuron, 75WG), Syngenta Professional Products Division. Greensboro, N.C.; Revolver(formasulfuron 0.19SC), Bayer Environmental Sciences, Montvale, N.J. Kentucky bluegrass received single or sequential herbicide applications. Initial and sequential application dates were 8 July and 6 Aug. 2004 in Indiana, 16 Aug. and 13 Sept. 2004 in Maryland, 13 July and 10 Aug. 2004 in Virginia, and 6 Aug. and 3 Sept. 2004 in New Jersey.

${ }^{y}$ Crop oil concentrate (1AL) adjuvant was included at $1 \%$ by volume.

${ }^{x}$ Nonionic surfactant (100SL) was included at $0.5 \%$ by volume.

and 6 Aug. 2004 in Indiana, 16 Aug. and 13 Sept. 2004 in Maryland, 13 July and 10 Aug. 2004 in Virginia, and 6 Aug. and 3 Sept. 2004 in New Jersey. Turf was mowed twice per week and sufficiently irrigated to prevent plant wilt. Mowing heights were $7.5 \mathrm{~cm}$ in New Jersey and Virginia, $5 \mathrm{~cm}$ in Maryland, and $5.6 \mathrm{~cm}$ in Indiana. Kentucky bluegrass was healthy and actively growing at all locations before herbicide treatments.

Kentucky bluegrass control was visually evaluated 4 and 8 WAIT on a percent scale where $0=$ no injury and $100=$ dead turf. Data were subjected to analysis of variance with SAS General Linear Model procedure (SAS, Cary, N.C). Mean separations were based on Fisher's protected LSD test at the 0.05 probability level.

\section{Results and Discussion}

Herbicide by location interaction was detected for kentucky bluegrass control; there- fore, results are presented by location. Single glyphosate applications completely controlled kentucky bluegrass by 8 WAIT at all locations (Table 3). Single glufosinate applications completely controlled kentucky bluegrass in New Jersey and Maryland by 4 WAIT. Single glufosinate applications controlled kentucky bluegrass only $7 \%$ by 8 WAIT in Indiana, while sequential applications controlled kentucky bluegrass $80 \%$ to $88 \%$ by 8 WAIT in Indiana and Virginia, respectively.

ACCase inhibiting herbicides provided variable levels of kentucky bluegrass control across locations. Two applications of clethodium in New Jersey completely controlled kentucky bluegrass 8 WAIT; however, single and sequential clethodim applications only provided $\leq 77 \%$ kentucky bluegrass control in Indiana, Maryland, and Virginia. Sequential applications of fluazifop-P completely controlled kentucky bluegrass 8 WAIT in New Jersey. In Indiana, Maryland, and Virginia, seqential applications of fluazifop-P controlled kentucky bluegrass $65 \%$ to $95 \%$ by 8 WAIT. Sequential applications of sethoxydim controlled kentucky bluegrass $93 \%$ and $98 \%$ by 8 WAIT in Indiana and New Jersey, respectively, but single and sequential applications gave $\leq 75 \%$ bluegrass control in Maryland and Virginia.

ACCase inhibiting herbicides had slower herbicidal effects relative to glyphosate and glufosinate which was similar to that noted on bentgrass species with fluazifop-P, clethodim, and sethoxydim (Hart et al., 2005). Kentucky bluegrass treated with single applications of clethodim and fluazifop-P in Indiana completely recovered by 8 WAIT. However, kentucky bluegrass control significantly increased with sequential applications of clethodim and fluzifop-P in Indiana, New Jersey, and Virginia but control did not improve from the sequential application in Maryland. Also, the sequential application of sethoxydim increased kentucky bluegrass control 53\% in New Jersey but did not improve control compared to single applications in Maryland and Virginia. Results suggest kentucky bluegrass control from ACC inhibiting herbicides may vary greatly by location, cultivar, and mowing height. Hart et al. (2005) noted herbicidal activity on creeping and colonial bentgrass (Agrosits tenuis Sibth.) with the ACCase inhibiting herbicides fluazifop-P, clethodim, and sethoxydim was slower relative to glyphosate, but nearly complete control was observed at 8 WAIT with fluazifop-P applied at $0.4 \mathrm{~kg} \cdot \mathrm{ha}^{-1}$. It was also noted that clethodim in a summer experiment in New Jersey and sethoxydim in summer experiments in New Jersey and Oregon was less consistent in controlling creeping, colonial, redtop (Agrostis gigantean Roth.), and dryland (Agrostis castellana Boiss. and Reut.) bentgrasses compared to fluazifop-P. However, in North Carolina, sequential applications of clethodim provided the highest levels of creeping bentgrass control 8 WAIT in both experiments. It was suggested higher levels of bentgrass control observed with sequential applications of fluazifop-P and sethoxydim in summer season experiments compared to the spring season experiment in North Carolina provide additional evidence that the efficacy of these herbicides may vary depending on site and environmental conditions.

ALS inhibiting herbicides had substantial activity on kentucky bluegrass, especially with sequential applications. Single foramsulfuron applications completely controlled kentucky bluegrass in Maryland and New Jersey by 8 WAIT. Single and sequential formasulfuron applications controlled kentucky bluegrass $65 \%$ to $68 \%$ by 8 WAIT in Virginia. In Indiana, single and sequential formasulfuron applications controlled kentucky bluegrass $2 \%$ and $82 \%$ by 8 WAIT, respectively.

Trifloxysulfuron controlled kentucky bluegrass $95 \%$ to $100 \%$ with single applications in Maryland, New Jersey, and Virginia 8 WAIT. In Indiana, single applications of trifloxysulfuron controlled kentucky bluegrass only $43 \% 8$ WAIT but sequential applications controlled kentucky bluegrass 100\%. In Maryland, single rimsulfuron applications completely controlled kentucky bluegrass by 8 WAIT whereas two applications were needed in New Jersey for complete control. Rimsulfuron controlled kentucky bluegrass $<20 \%$ with single applications in Indiana and Virginia. Sequential rimsulfuron applications controlled kentucky bluegrass 98\% in Indiana but did not improve control from single applications in Virginia. In Virginia, the kentucky bluegrass stand was 9 years old and turfmaturity likely reduced rimsulfuron efficacy relative to younger stands in Indiana, New Jersey, and Maryland. Kentucky bluegrass cultivars, soils, and environmental conditions also differed across locations and may have contributed to differences in rimsulfuron efficacy.

Sequential applications of trifloxysulfuron and formasulfuron did not increase levels of control from single applications. In Virginia and Maryland, sequential applications of rimsulfuron did not improve kentucky bluegrass control compared to single rimsulfuron applications. Results suggest ALS inhibitors have slow but substantial herbicide activity on kentucky 
Table 3. Percent kentucky bluegrass reductions following herbicide treatments in Indiana, New Jersey, Virginia, and Maryland, July to September 2004.

\begin{tabular}{|c|c|c|c|c|c|c|c|c|c|c|}
\hline \multirow[b]{3}{*}{ Herbicide $^{z}$} & \multirow{3}{*}{$\begin{array}{c}\text { Rate } \\
\left(\mathrm{kg} \cdot \mathrm{ha}^{-1} \text { a.i. }\right)\end{array}$} & \multirow[b]{3}{*}{ Application ${ }^{y}$} & \multicolumn{8}{|c|}{ Kentucky bluegrass reduction (\%) (weeks after initial treatments) } \\
\hline & & & \multicolumn{2}{|c|}{ Indiana } & \multicolumn{2}{|c|}{ New Jersey } & \multicolumn{2}{|c|}{ Virginia } & \multicolumn{2}{|c|}{ Maryland } \\
\hline & & & 4 & 8 & 4 & 8 & 4 & 8 & 4 & 8 \\
\hline \multirow[t]{2}{*}{ Clethodim $^{x}$} & 0.28 & 1 & 8 & 0 & 61 & 44 & 20 & 31 & 18 & 77 \\
\hline & & 2 & 15 & 60 & 61 & 100 & 14 & 63 & 10 & 76 \\
\hline \multirow[t]{2}{*}{ Fluazifop- $\mathrm{p}^{\mathrm{x}}$} & 0.43 & 1 & 50 & 0 & 59 & 79 & 10 & 59 & 5 & 72 \\
\hline & & 2 & 53 & 95 & 54 & 100 & 20 & 65 & 7 & 74 \\
\hline \multirow[t]{2}{*}{ Foramsulfuron } & 0.03 & 1 & 32 & 2 & 65 & 93 & 18 & 68 & 93 & 99 \\
\hline & & 2 & 45 & 82 & 68 & 100 & 19 & 69 & 93 & 99 \\
\hline \multirow{2}{*}{ Glufosinate } & 1.12 & 1 & 65 & 7 & 100 & 100 & 99 & 84 & 98 & 99 \\
\hline & & 2 & 70 & 80 & 100 & 100 & 100 & 88 & 98 & 100 \\
\hline \multirow{2}{*}{ Glyphosate } & 1.68 & 1 & 98 & 100 & 100 & 100 & 100 & 100 & 100 & 100 \\
\hline & & 2 & 97 & 100 & 100 & 100 & 100 & 100 & 100 & 100 \\
\hline \multirow[t]{2}{*}{ Rimsulfuron $^{w}$} & 0.03 & 1 & 37 & 3 & 64 & 54 & 6 & 16 & 98 & 100 \\
\hline & & 2 & 40 & 98 & 60 & 100 & 6 & 18 & 98 & 100 \\
\hline \multirow[t]{2}{*}{ Sethoxydim ${ }^{x}$} & 0.53 & 1 & 37 & 7 & 58 & 44 & 31 & 73 & 13 & 75 \\
\hline & & 2 & 63 & 93 & 60 & 98 & 16 & 64 & 15 & 73 \\
\hline \multirow{2}{*}{ Trifloxysulfuron ${ }^{\mathrm{w}}$} & 0.03 & 1 & 72 & 43 & 69 & 96 & 31 & 95 & 99 & 100 \\
\hline & & 2 & 65 & 100 & 64 & 100 & 40 & 96 & 99 & 100 \\
\hline Untreated & --- & --- & 0 & 0 & 0 & 0 & 0 & 0 & 0 & 0 \\
\hline LSD 0.05 & & & 15 & 22 & 7 & 16 & 13 & 13 & 13 & 25 \\
\hline
\end{tabular}

${ }^{2}$ Herbicide products applied were as follows. Envoy (clethodim 0.94EC), Valent U.S.A. Corp., Walnut Creek, Calif.; Finale (glufosinate 1SL), Aventis Environmental Science USA LP, Montvale, N.J.; Fusilade II (fluazifop-P 2EC) Turf and Ornamental, Syngenta Professional Products Division, Greensboro, N.C.; Roundup Pro (glyphosate 3SL), Monsanto Co., St. Louis, Mo.; TranXit (rimsulfuron 25DF), Griffin L.L.C., Valdosta, Ga.; Vantage (sethoxydim 1EC), BASF Corp. and MicroFlo Co., Memphis, Tenn.; Monument (trifloxysulfuron 75WG), Syngenta Professional Products Division, Greensboro, N.C.; Revolver (formasulfuron 0.19SC), Bayer Environmental Sciences, Montvale, N.J.

${ }^{y}$ Kentucky bluegrass received one or two herbicide applications with the second application made 4 weeks after initial treatments. Ratings on week 4 were made before the second herbicide application. Initial and sequential application dates were 8 July and 6 Aug. 2004 in Indiana, 16 Aug. and 13 Sept.2004 in Maryland, 13 July and 10 Aug. 2004 in Virginia, and 6 Aug. and 3 Sept. 2004 in New Jersey.

${ }^{x}$ Crop oil concentrate (1AL) adjuvant was included at $1 \%$ by volume.

"Nonionic surfactant (100SL) was included at $0.5 \%$ by volume.

bluegrass. Compared to experiments with bentgrass species, the ALS inhibitor sulfosulfuron exhibited similar speed of herbicide activity on bentgrass but control levels ranged from $80 \%$ to $92 \%$ by 8 WAIT (Hart et al., 2005).

\section{Conclusion}

Herbicides that effectively control kentucky bluegrass will be critical when glyphosate-resistant cultivars are introduced to the turf industry. ACCase inhibitors did not provide complete control with single applications and sequential applications provided erratic levels of kentucky bluegrass control across locations. Clethodim had the least amount of efficacy on kentucky bluegrass. Single and sequential applications of ALS inhibitors provided considerable kentucky bluegrass control. Rimsulfuron applications provided inconsistent kentucky bluegrass control across locations but trifloxysulfuron gave the greatest control of all herbicides other than glyphosate. From these experiments, glufosinate and trifloxysulfuron possess the greatest potential for controlling glyphosate-resistant kentucky bluegrass when renovation is desired. ACCase inhibiting herbicides do not appear to be viable alternatives to glyphosate for kentucky bluegrass control.

Further investigations are needed with glufosinate for long-term control of kentucky bluegrass. Researchers have observed that perennial grasses such as tall fescue (Festuca arundinacea Schreb.) and johnsongrass (Sorghum halepense L. Pers.) may exhibit significant regrowth following rapid desiccation from glufosinate (Barker et al., 2003; Johnson et al., 2003). Hart et al. (2005) noted glufosinate controlled creeping bentgrass in New Jersey equivalent to glyphosate but dryland bentgrass control with glufosinate was less than with glyphosate. The researchers also noted that all bentgrass lines recovered from glufosinate injury in summer experiments in Oregon. Although glufosinate provides rapid desiccation of existing turf, species variability and location may significantly influence regrowth following glufosinate use and warrants further investigation on kentucky bluegrass. Sequential glufosinate treatments will likely be needed for complete kentucky bluegrass control in environments and on plants that have potential for post-treatment recovery.

Turfgrass establishment following kentucky bluegrass desiccation may also be affected by herbicide residual activity. Reseeding and overseeding is recommended no sooner than 6 weeks after trifloxysulfuron applications which may be a significant limitation when using this herbicide for renovations (Syngenta, 2003a). Glufosinate has no reseeding restrictions and potentially less soil residual activity may be advantageous compared to trifloxysulfuron (Aventis Environmental Science USA, 2001). Timing of reseeding operations of different turfgrass species may vary following glufosinate and trifloxysulfuron use and require further research. Since weeds and other grass species, such as annual bluegrass (Poa annua L.), may be present in turfgrass stands, investigations are needed with tank mixtures of herbicides with glyphosate to elucidate potential antagonistic effects when total renovations are desired.

\section{Literature Cited}

Amrhein, N., B. Deus, P. Gehrke, and H.C. Steinrucken. 1980. The site of the inhibition of the shikimate pathway by glyphosate II. Interference of glyphosate with chorismate formation in vivo and in vitro. Plant Physiol. 66:830-834.
Aventis Environmental Science USA. 2001. Finale $\AA$ product label. Aventis Environ. Sci. USA LP., Montvale, N.J.

Askew, S.D., J.B. Beam, and D.C. Riego. 2004. Alternatives to glyphosate for creeping bentgrass control. Proc. N.E. Weed Sci. Soc. 58:115.

Atkinson, D. 1985. Toxicological properties of glyphosate-A summary, p. 210-216. In: E. Grossbard and D. Atkinson (eds.). The herbicide glyphosate. Butterworth and Co., Toronto, Canada.

Barker, W.L., S.D. Askew, J.B. Beam, and D.C. Riego. 2003. Diquat plus glyphosate for rapidsymptom vegetation control in turf. Proc. N.E. Weed Sci. Soc. 57:73.

BASF Corp. and MicroFlo Co. 2002e. Vantage ${ }^{\circledR}$ product label. BASF Corp. MicroFlo Co., Memphis, Tenn.

Bayer Environmental Sciencess. 2003b. Revolver ${ }^{\circledR}$ product label. Bayer Environ. Sci., Montvale, N.J.

Beard, J.B. 1973. Turfgrass: Science and culture. Prentice-Hall, Englewood Cliffs, N.J.

Burton, J.D., J.W. Gronwald, D.A. Somers, B.G. Gengenbach, and D.L. Wyse. 1989. Inhibition of corn acetyl-CoA carboxylase by cyclohexanedinone and aryloxyphenoxypropionate herbicides. Pesticide Biochem. Physiol. 34: 76-85.

Chaleff, R.S. and C.J. Mauvais. 1984. Acetolactate synthase is the site of action of two sulfonylurea herbicides in higher plants. Science 224:1443-1445.

Focke, M. and H.K. Lichtenthaler. 1987. Inhibition of the acetyl-CoA carboxylase of barley chloroplasts by cycloxydim and sethoxydim. Z. Naturforsch. 42c:1361-1363.

Griffin L.L.C. 2002d. TranXit ${ }^{\circledR}$ product label. Griffin L.L.C., Valdosta, Ga.

Hart, S.E., F.H. Yelverton, E.K. Nelson, D.W. Lycan, and G.M. Henry. 2005. Response of glyphosate resistant and susceptible bentgrass (Agrostis spp.) to postemergence herbicides. Weed Technol. 19:549-555.

Higgins, J.M., L.B. McCarty, T. Whitwell, and L.C. Miller. 1987. Bentgrass and bermudagrass 
putting green turf tolerance to postemergence herbicides. HortScience 22:248-250.

Johnson, W.G., J. Li, and J.D. Wait. 2003. Johnsongrass control, total nonstructural carbohydrates in rhizomes, and regrowth after application of herbicides used in herbicide-resistant corn ( $\mathrm{Zea}$ mays). Weed Technol. 17:36-41.

Lee, L. 1996. Turfgrass biotechnology. Plant Sci. 115:1-8.

Logusch, E.W., D.M. Walker, J.F. McDonald, and J.E. Franz. 1991. Inhibition of plant glutamine synthetases by substituted phosphinothricins. Plant Physiol. 95:1057-1062.

Monsanto Co. 2002c. Roundup $®$ Pro product label. Monsanto Co., St. Louis, Mo.
Padgette, S.R., D. Re, G.F. Barry, D.E. Eichholtz, X. Delannay, R.L. Fuchs, G.M. Kishore, and R.T. Fraley. 1996. New weed control opportunities: Development of soybeans with a Roundup Ready $^{\text {TM }}$ gene, p. 54-80. In: S.O. Duke(ed.). Herbicide-resistant crops: Agricultural, economic, environmental, regulatory, and technological aspects. CRC Press, Boca Raton, Fla.

Shaner, D.L., P.C. Anderson, and M.A. Stidham. 1984. Imidazolinones: Potent inhibitors of acetohydroxy acid synthase. Plant Physiol. 76:545-546

Stidham, M.A. 1991. Herbicides that inhibit acetohydroxy acid synthase. Weed Sci. 39:428-434.

Syngenta Professional Products Division. 2002b.
Fusilade® II Turf and Ornamental product label. Syngenta Professional Products Div., Greensboro, N.C.

Syngenta Professional Products Division. 2003a. Monument ${ }^{\circledR}$ product label. Syngenta Professional Products Div., Greensboro, N.C.

Valent U.S.A. Corp. 2002a. Envoy® product label. Valent U.S.A. Corp, Walnut Creek, Calif.

Wild, A., H. Sauer, and W. Ruhle. 1987. The effect of phosphinothricin (glufosinate) on photosynthesis I. Inhibition of photosynthesis and accumulation of ammonia. Z.Naturforsch. 42:263-269.

Wild, A. and C. Wendler. 1993. Inhibitory action of glufosinate on photosynthesis. Z. Naturforsch. 48:369-373. 